\title{
Influence of the Emotional intelligence on General well being of Government Welfare Residential School Children
}

\author{
${ }^{1}$ Maharishi. R, ${ }^{2}$ Ganesh Kumar. J \\ ${ }^{1,2}$ M.Phil Research Scholar, Periyar University, Salem-11, Tamil nadu, India.
}

\begin{abstract}
In day to day life, children encounter many problems related to general well being. Emotional intelligence is essential for every child to handle their problems by recognizing and managing their emotions, being able to motivate oneself and restrain one's impulses, recognizing and managing others' emotions and handling interpersonal relationships in an effective manner. The objective of this study is to know the influence of emotional intelligence on general well being of the children in the government welfare residential schools in Dharumapuri district. The samples for the study were collected from 5 different government welfare residential schools of Dharumapuri districts in Tamil Nadu. A total 100 students were selected out which 55 are male and 45 are female. The sample for this study was collected using simple random sampling technique. The data was analyzed using appropriate statistical techniques. The results elucidate emotional intelligence is not significantly related to general well-being of government welfare residential school children, there is no significant difference in emotional intelligence and general well-being of students based on their gender of government welfare residential school children, there is a significant difference in emotional intelligence based on their type of family of government welfare residential school children and also there is no significant difference in general well-being based on their type of family of government welfare residential school children.
\end{abstract}

Key words: emotional intelligence, general well being, government residential school students, dharumapuri.

\section{Introduction}

Emotional intelligence is the ability or tendency to perceive, understand, regulate and harness emotions adoptively in self and in others (schutte et al 1998). Researchers have conceptualised emotional intelligence both as ability and as a trait. It includes the ability to understand and regulate others as well as one's own emotion. People who have control over their life can manage their feelings well and deal effectively with other people's feelings while the people who cannot have control over their emotional life, fight inner battles that sabotage their ability to focus on work and think clearly. While the role of emotional intelligence influence a wide range of action, thought and affect, including those associated with general well-being - general selfevaluations and patterns of behaviour, coping, and emotion. First, as emotional intelligence also contribute to adolescents' well-being, Schools and school achievement are obviously important, at least in a general way, to adolescents' self-evaluations and well-being.

The person who succeeds in managing emotions can bounce back far more quickly from life's setbacks. It has been found that there is link between emotional intelligence and interpersonal relations, empathic feelings, perspective taking, self-monitoring in social situation, social skills, cooperativeness, affectionate relationship and satisfaction in relationships. All emotionally intelligent people are more successful and have less mental health problems as they handle emotional stress productively. It leads to a feeling of wellbeing. Verma et al. (1998) defined well-being as contentment, happiness, satisfaction with life's experiences and one's role in the world of work, Sense of achievement, utility, belongingness and no distress, dissatisfaction or worry, etc. Coleman (1996) believes that high emotional intelligence is critical for one's success in the world.

Emotional intelligence appears to be an important set of psychological abilities that relate the life success. It is a matter more than IQ for character, health and lifelong achievements due to empathy and communication skills as well social and leadership skills that are central to success in life and personal relationships.

Hypothesis

1. School students differ in their emotional intelligence on the basis of gender and type of family.

2. School students differ in their General Well-being on the basis of gender and type of family

3. There is a significant relationship between Emotional intelligence and General well-being of school students. 


\section{Research Method}

Sample: The samples for the study were collected from 5 different government welfare residential schools of Dharmapuri districts in Tamil nadu. A total 100 students were selected out which 55 are male and 45 are female. Simple random sampling design was used.

Materials: Two measures were used to collect data. The Emotional Quotient Inventory by Bar-On and General Well-Being by verma and verma are used to collect the data along with personal data. Emotional Quotient Inventory is a self- report questionnaire consists of 66 items which measures ten different components of emotional intelligence viz; 1)Self-regard 2)Interpersonal relationship 3) Impulse control 4) Problem solving 5) Emotional- self- awareness 6) Flexibility.7) Reality testing 8) Stress-tolerance 9) Assertiveness 10) Empathy, at least to a degree there are five response categories viz, "not true", "seldom true", "sometime true", and "true". Negative and positive items were scored separately. The total score of all the 66 items yield the total emotional quotient score of the person. General well-being scale consists 20 items and range is from 0 to 20. A high score indicates a better feeling of well-being.

Procedure: as per objectives of the study the respondents were personally contacted in their schools. The measure of general well-being was given to high and low scorers' boys and girls on emotional intelligence. The filled questionnaires were collected and were scored according to the procedure given in the manual. The data collected were analysed using appropriate statistical tools. Descriptive analysis (mean, standard deviation) was used to find the level of emotional intelligence and general well-being among the ninth school students. ' $t$ ' test were used to assess the difference in emotional intelligence and general well-being of students based on their gender and type of family. The correlations were used for find out relationship between emotional intelligence and general well-being. The influence of emotional intelligence on general well-being was assessed using regression.

\section{Results And Disscussion}

Hypothesis 1: School students differ in their emotional intelligence on the basis of gender and type of family.

Table: 3 Emotional intelligence and general well-being of students on the basis of gender

\begin{tabular}{|c|c|c|c|c|}
\hline & Gender & $\mathrm{N}$ & Mean & $\mathrm{T}$ \\
\hline \multirow[t]{2}{*}{ General Well Being } & Male & 54 & 12.07 & \\
\hline & Female & 46 & 11.89 & .368 \\
\hline \multirow[t]{2}{*}{ Self regard } & Male & 53 & 19.26 & .369 \\
\hline & Female & 46 & 19.07 & \\
\hline \multirow[t]{2}{*}{ Interpersonal Relationship } & Male & 54 & 15.06 & .272 \\
\hline & Female & 46 & 14.22 & \\
\hline \multirow[t]{2}{*}{ Impulse Control } & Male & 54 & 9.06 & 1.173 \\
\hline & Female & 46 & 9.39 & \\
\hline \multirow[t]{2}{*}{ Problem Solving } & Male & 54 & 12.19 & .577 \\
\hline & Female & 46 & 13.07 & \\
\hline \multirow[t]{2}{*}{ Emotional Self Awareness } & Male & 54 & 11.22 & 1.197 \\
\hline & Female & 46 & 12.30 & \\
\hline \multirow[t]{2}{*}{ Flexibility } & Male & 54 & 15.70 & 1.537 \\
\hline & Female & 46 & 14.89 & \\
\hline \multirow[t]{2}{*}{ Reality Testing } & Male & 54 & 11.91 & 1.126 \\
\hline & Female & 46 & 12.33 & \\
\hline \multirow[t]{2}{*}{ Stress Tolerance } & Male & 54 & 17.37 & .685 \\
\hline & Female & 46 & 16.39 & \\
\hline \multirow[t]{2}{*}{ Assertiveness } & Male & 54 & 11.41 & 1.330 \\
\hline & Female & 46 & 11.98 & \\
\hline \multirow[t]{2}{*}{ Empathy } & Male & 54 & 11.00 & .851 \\
\hline & Female & 46 & 11.07 & \\
\hline \multirow[t]{2}{*}{ Total Emotional Intelligence } & Male & 53 & 134.38 & .120 \\
\hline & Female & 46 & 134.70 & \\
\hline
\end{tabular}


From Table -1, it is observed that the ' $t$ ' values are not significant for general Well-Being, Emotional intelligence and its dimensions on the basis of gender, hence the hypothesis is not accepted. It is concluded that the school students do not differ significantly in their Emotional intelligence and general Well-Being on the basis of gender. family

Hypothesis 2: School students differ in their General Well-being on the basis of gender and type of

Table: 2 Emotional intelligence and general well-being of student on the basis of type of family

\begin{tabular}{|c|c|c|c|c|c|}
\hline & $\begin{array}{l}\text { Family } \\
\text { Type }\end{array}$ & $\mathrm{N}$ & Mean & Std. Deviation & $\mathrm{t}$ \\
\hline \multirow[t]{2}{*}{ General Well Being } & Nuclear & 42 & 11.48 & 2.462 & \\
\hline & Joint & 58 & 12.36 & 2.418 & 1.794 \\
\hline \multirow[t]{2}{*}{ Self regard } & Nuclear & 42 & 18.26 & 3.832 & 1.789 \\
\hline & Joint & 57 & 19.84 & 3.437 & \\
\hline \multirow[t]{2}{*}{ Interpersonal Relationship } & Nuclear & 42 & 14.81 & 3.380 & $2.117 *$ \\
\hline & Joint & 58 & 14.57 & 3.647 & \\
\hline \multirow[t]{2}{*}{ Impulse Control } & Nuclear & 42 & 8.33 & 2.936 & .340 \\
\hline & Joint & 58 & 9.84 & 2.726 & \\
\hline \multirow[t]{2}{*}{ Problem Solving } & Nuclear & 42 & 12.36 & 3.944 & $2.618^{*}$ \\
\hline & Joint & 58 & 12.76 & 3.516 & \\
\hline \multirow[t]{2}{*}{ Emotional Self Awareness } & Nuclear & 42 & 12.31 & 3.339 & .526 \\
\hline & Joint & 58 & 11.29 & 3.603 & \\
\hline \multirow[t]{2}{*}{ Flexibility } & Nuclear & 42 & 15.31 & 3.653 & 1.453 \\
\hline & Joint & 58 & 15.34 & 3.654 & \\
\hline \multirow[t]{2}{*}{ Reality Testing } & Nuclear & 42 & 12.62 & 2.358 & .048 \\
\hline & Joint & 58 & 11.72 & 3.427 & \\
\hline \multirow[t]{2}{*}{ Stress Tolerance } & Nuclear & 42 & 16.76 & 3.560 & 1.546 \\
\hline & Joint & 58 & 17.03 & 3.774 & \\
\hline \multirow[t]{2}{*}{ Assertiveness } & Nuclear & 42 & 11.40 & 2.988 & .368 \\
\hline & Joint & 58 & 11.86 & 3.620 & \\
\hline \multirow[t]{2}{*}{ Empathy } & Nuclear & 42 & 11.76 & 2.783 & .691 \\
\hline & Joint & 58 & 10.50 & 2.584 & \\
\hline \multirow{2}{*}{$\begin{array}{l}\text { Total } \\
\text { Intelligence }\end{array}$} & Nuclear & 42 & 133.93 & 10.438 & $2.306^{*}$ \\
\hline & Joint & 57 & 134.96 & 10.085 & \\
\hline
\end{tabular}

*Significance at 0.05 levels

From Table -2, it is observed that the ' $t$ ' values are significant for total emotional intelligence and its two dimensions such as problem solving and interpersonal relationships on the basis of type of family, hence the hypothesis is accepted. It is concluded that the school students differ significantly in their Emotional intelligence on the basis of type of family. It is note down from table that students come from joint family have more emotional intelligence than students from nuclear family. It s a warning sign for youngster those who are prefer for nuclear family system. Joint family systems enhance interpersonal relationships and problem solving skills of school students and it help to develop emotional intelligence. It's vividly seen it this table students belongs to joint family system scored higher score in problem solving and inter personal relationship than the students belongs to nuclear family. However general well-being of school students does not differ significantly on the basis of types of family.

Table: 3 Relationship between emotional intelligence and General well-being of students.

\begin{tabular}{|ll|l|l|l|l|l|l|l|l|l|l|l|}
\hline & & S R & I R & I C & P S & E SA & F & R T & S T & A & E & Total EI \\
\hline $\begin{array}{l}\text { General } \\
\text { Being }\end{array}$ & Well & .006 & .127 & .160 & .161 & .099 & .003 & .039 & .075 & .064 & .015 & .058 \\
\hline
\end{tabular}


From Table- 3, it is found that there is no significant relation among the Emotional intelligence and General Well-Being of school students. Hence the hypothesis is accepted and it is concluded that the emotional intelligence of school students is not significantly related to their General well-being.

Conclusion

Emotional intelligence is not significantly related to general well-being of government welfare residential school children.

There is no significant difference in emotional intelligence and general well-being of students based on their gender of government welfare residential school children.

There is a significant difference in emotional intelligence based on their type of family of government welfare residential school children.

There is no significant difference in general well-being based on their type of family of government welfare residential school children.

\section{References}

[1]. Afolabi, Olukayade. (2009). "Influence of emotional intelligence and need for achievement on interpersonal relations and acad emic achievement of undergraduates", Educational research Quarterly, vol33 n2 p60-72.

[2]. Bar-On, R. (1997). The Emotional Quotient Inventory (EQ-I): a test of emotional intelligence. Toronto: Multi-Health Systems.

[3]. Doalip singh. (2006). Emotional Intelligence at Work ( ${ }^{\text {rd }}$ edition), Response Books New Delhi.

[4]. European commission. (2011). Euro barometer qualitative studies "Well-being". Aggregate report September 2011.

[5]. Fridman H.S. (2011). Oxford Handbook of Health Psychology. Oxford University Press, New York.

[6]. Goleman, D. (1996). Emotional Intelligence: why it can matter more than IQ. New York:

[7]. Jane Ogden. (2004). Health Psychology ( ${ }^{\text {rd }}$ edition). Open University Press, London.

[8]. Norman M.Bradbourn. The structure of Psychological Well-Being. Aldine publishing company, Chicago, Illinois-60605.

[9]. Robin Dimatteo and Martin L.R. Health Psychology. Dorling kindersky, India pvt.ltd.

[10]. Verma and Verma. (1989). Manual of PGI general well-being measurer, Ankur Psychological Agency, Lucknow. 